\title{
Pengaruh Gaya Kepemimpinan, Motivasi Kerja dan Budaya Organisasi terhadap Kinerja Karyawan pada Bank Muamalat Indonesia Cabang Surakarta
}

Agus Marimin

Institut Agama Islam Negeri (IAIN) Surakarta

E-mail: agus.marimin@gmail.com

\begin{abstract}
:
Human resource represent the key factor go to the success, along of human resource activator in operational company. The purpose if this research is to prove the influence of leadership style, work motivation, and organization culture toward employee performance of Bank Muamalat branch Indonesia Surakarta. The method used in this research is survey which using questioner for getting data. The respondents of this research are all of employee at Bank Muamalat branch Indonesia Surakarta. The data that get in this research is processed with program SPSS version 16.00. The test is done with linear regression model, $\mathrm{t}$ test, $\mathrm{f}$ test, $\mathrm{R}^{2}$ and Classic Assumption. Conclusion of this research is there is influence which significance of among leadership style, motivation, and organization culture toward employee performance of Bank Muamalat branch Indonesia Surakarta as individually.
\end{abstract}

Keywords: Leadership Style, Work Motivation, Organization Culture

\section{Pendahuluan}

Gaya kepemimpinan merupakan pola-pola perilaku konsisten yang diterapkan pemimpin dengan melalui orang lain pada saat mempengaruhi orang lain. Gaya kepemimpinan bukan merupakan pendapat pemimpin tentang perilaku mereka, tetapi bagaimana persepsi orang lain terutama bawahannya tentang perilaku kepemimpinannya. Berdasarkan penelitian yang dilakukan Ohio State University akhir tahun 1940, terdapat dua dimensi gaya kepemimpinan yaitu struktur inisiatif (initiating structure) dan pertimbangan (consideration). Gaya kepemimpinan struktur inisiatif cenderung 
berorientasi pada tugas dan tanggung jawab yang diberikan kepada bawahan. Sedangkan gaya kepemimpinan pertimbangan cenderung fleksibel, yang melibatkan bawahan dalam pengambilan keputusan.

Menurut John R Shermerhorn (2000: 12), suatu organisasi untuk dapat bertahan hidup harus mengoptimalkan fungsi-fungsi manajemen, meliputi perencanaan (planning), pengorganisasian (organizing), pengarahan (directing), dan pengendalian (control). Fungsi-fungsi manajemen merupakan pondasi dari fungsi kepemimpinan.

Kepemimpinan merupakan kemampuan untuk mempengaruhi suatu kelompok demi pencapaian tujuan (Robbins, 1999: 19). Bentuk pengaruh tersebut dapat secara formal seperti tingkat manajerial pada suatu organisasi. Dari waktu ke waktu kepemimpinan selalu menjadi perhatian manusia. Kepemimpinan dibutuhkan manusia karena adanya suatu keterbatasan dan kelebihan tertentu pada manusia. Sejarah umat manusia telah memperlihatkan kepada kita bahwa zaman dahulu manusia yang hidup berkelompok sudah mengenal adanya pemimpin. Kebutuhan akan pemimpin semakin mendesak manakala muncul tuntutan-tuntutan yang baru akibat perkembangan yang terjadi pada masyarakat, seperti perkembangan globalisasi, liberalisasi perdagangan, lingkungan hidup dan sebagainya.

Gaya kepemimpinan merupakan norma perilaku yang digunakan oleh seseorang pada saat orang tersebut mencoba mempengaruhi perilaku orang lain seperti yang ia inginkan. Dalam budaya organisasi, suatu gaya kepemimpinan sangat diperlukan untuk mengembangkan lingkungan kerja yang kondusif dan meningkatkan kinerja bagi karyawan sehingga diharapkan akan menghasilkan produktivitas yang tinggi. Kinerja itu sendiri dapat diartikan sebagai kemampuan karyawan dalam melaksanakan keseluruhan tugas-tugas yang menjadi tanggung-jawabnya.

Penelitian tentang gaya kepemimpinan telah berkembang pesat dan fokus perhatiannya adalah seputar efektifitas kepemimpinan yang menghubungkan perilaku pemimpin dengan tingkat kinerja bawahan (Fiedler, 1967 dalam Jiambalvo dan Pratt, 1982).

Maka dari itu faktor kepemimpinan sebagai salah satu fungsi manajemen (directing) yang didefinisikan sebagai kegiatan manajer atau pimpinan yang berusaha memberikan pengarahan kepada bawahannya agar mereka 
melaksanakan kebijaksanaan yang telah digariskan, guna menghindari kemacetan dan penyimpangan, sangat menentukan jalannya organisasi (Mochtar, 1996: 113). Inti kesuksesan suatu budaya organisasi pada dasarnya terletak pada pemimpinnya. Pemimpin yang tidak dapat menjalankan tugasnya, meski ditopang dengan sarana yang baik dan modal yang cukup, tetap tidak akan dapat membawa organisasi atau perusahaan kepada keberhasilan. Suksesnya suatu badan usaha atau majunya perusahaan selalu dimulai dari pemimpin yang berkualitas dan amanah.

Manusia adalah faktor yang sangat menentukan dalam perusahaan baik perusahaan jasa maupun perusahaan barang, terutama pada industri yang menggunakan tenaga manusia. Apabila manusia dengan semua perilaku baiknya, yang menjunjung nilai organisasi yang baik, dapat dimanfaatkan secara optimal, maka kemampuannya ini merupakan kekuatan yang potensial dalam mencapai tujuan perusahaan.

Fungsi kepemimpinan dan budaya organisasi dalam usaha bisnis merupakan elemen yang sangat penting dalam pengelolaan sumber daya manusia. Selain memberikan pengarahan, juga memberikan motivasi dalam upaya peningkatan kinerja karyawan. Untuk mengembangkan kemajuan dan perkembangan kinerja karyawan, sangat tergantung kepada sumber daya manusia sebagai pengelola langsung. Oleh sebab itu kepemimpinan mempunyai peran besar dalam meningkatkan kinerja karyawan. Sikap dan gaya serta perilaku kepemimpinan seorang pemimpin sangat besar pengaruhnya terhadap budaya organisasi yang dipimpin bahkan sangat berpengaruh terhadap kinerja karyawan dalam organisasi tersebut.

Gaya kepemimpinan merupakan faktor eksternal yang memungkinkan dapat mempengaruhi kinerja karyawan. Gaya kepemimpinan yang disesuaikan dengan karakteristik karyawan dan karakateristik perusahaan, memungkinkan karyawan memiliki tingkat kinerja yang tinggi. Sebaliknya gaya kepemimpinan yang tidak disesuaikan dengan karakteristik karyawan dan tugas yang ada, dapat mendorong karyawan merasa kurang bersemangat dalam bekerja (tidak memiliki kinerja yang bagus) atau bahkan kehilangan semangat kerja, sehingga menyebabkan karyawan tidak bersungguh-sungguh dalam bekerja dan perhatian yang tidak terpusat pada pekerjaan. Keadaan seperti ini berpengaruh terhadap hasil pekerjaan yang tidak optimal, juga 
terabaikannya kualitas dan kuantitas produksi. Tentu saja hal ini perlu mendapat perhatian khusus, karena dapat mengganggu kelancaran kegiatan perusahaan.

Penelitian ini dilakukan di Bank Muamalat Cabang Surakarta, karena memiliki beberapa alasan di antaranya adalah BMI merupakan lembaga perbankan syariah pertama di Indonesia yang mampu survive menghadapi lingkungan bisnis di kala bank-bank yang lainnya mengalami likuidasi pada tahun 1997 sehingga dapat eksis sampai sekarang dan cukup disorot oleh para pelaku bisnis, yang akhirnya merupakan teladan bagi perbankan syariah lainnya dalam perkembangan perekonomian Islam. Selain itu ada kalangan masyarakat yang mengklaim bahwasanya bank syariah hanya merupakan kedok, artinya keseluruhan sistem dan operasional bank syariah masih meminjam dan mengadopsi konsep perbankan konvensional. Alasan lain yaitu, BMI memiliki konsep atau nilai budaya organisasi yang unik, yaitu nilai-nilai celestial management di mana konsep tersebut berbeda dengan lembaga perbankan syariah lainnya.

Berdasarkan uraian di atas, maka dapat dirumuskan permasalahan yaitu: (1) Apakah terdapat pengaruh yang signifikan antara gaya kepemimpinan, motivasi kerja dan budaya organisasi terhadap kinerja karyawan pada Bank Muamalat Indonesia Cabang Surakarta?; (2) Manakah di antara tiga variabel di atas, yang berpengaruh dominan terhadap kinerja karyawan pada Bank Muamalat Indonesia Cabang Surakarta.

\section{Penelitian Terdahulu}

Penelitian ini dilakukan untuk menjawab rumusan permasalahan di atas, dan sebagai analisis pembanding atau pembeda antara penelitian ini dan penelitian terdahulu, penulisan memaparkan dan menjelaskan signifikansi penelitian-penelitian terdahulu guna mendapatkan kerangka berpikir yang tepat.

Pakar di bidang budaya organisasi yang termasuk dalam deretan peneliti awal adalah Richard T. Pascale dan Anthony G. Athos sekitar tahun 1981. Mereka menemukan model organisasi yang dikenal model Seven-S 
McKinesy (structure, strategy, shared, staff, style, system dan skill). Kemudian istilah ini dikembangkan oleh Thomas S. Peterdan Robert H. Waterman. Hasil dari penelitian ini menunjukkan bahwa, budaya organisasi yang kuat memiliki ciri-ciri yang berorientasi pada: (1) Tindakan, bukan hanya mengembangkan konsep yang dianalisis terus menerus; (2) Dekat dengan pelanggan, yaitu dengan cara mempelajari kemauan atau keinginan mereka dan memelihara hubungan dengan mereka; (3) Memberikan otonomi dan menumbuhkan semangat kewirausahawan pada karyawan dengan cara memecah organisasi ke dalam kelompok kecil dan merangsang mereka untuk berfikir secara independen; (4) Produktivitas, dengan cara menumbuhkan kesadaran bahwa usaha setiap karyawan sangat dibutuhkan dan penghasilan mereka ditentukan oleh kesuksesan bersama; (5) Eksekutif (pemimpin) yang selalu peduli dengan urusan bisnis yaitu dengan hanya menjelaskan bisnis yang diketahui dan paling dikuasai seluk beluknya; (6) Organisasi yang ramping dengan jumlah personil yang sedikit tetapi kaya dengan fungsi; (7) Memberikan kelonggaran kepada karyawan dengan ikatan tata nilai yang harus dipegang teguh (Ancok: 2003).

Penelitian lainnya adalah yang dilakukan oleh Ida Ayu Brahmasari dan Agus Suprayetno, berjudul "Pengaruh motivasi kerja, kepemimpinan dan budaya organisasi terhadap kepuasan kerja karyawan serta dampaknya pada kinerja perusahaan (studi kasus pada PT. Pei Hai International Wiratama Indonesia)". Penelitian ini mengunakan analisis data SEM (Structural Equation Modelling) melaluai program AMOS versi 4.0 dapat disimpulkan hasilnya motivasi, kepemimpinan, dan budaya organisasi perpengaruh positif terhadap kinerja karyawan. Dengan demikian, variabel-variabel penelitian ini dapat dilakukan guna untuk mengetahuai kinerja suatu perusahaan tertentu (Brahmasari dan Suprayetno, 2008: 124-135).

\section{Landasan Teori}

\section{Gaya dan Fungsi Kepemimpinan}

Kepemimpinan merupakan masalah yang sangat penting dalam manajemen. Bahkan ada yang menilai bahwa kepemimpinan adalah jantungnya atau intinya manajemen. Pemimpin atau kepemimpinan merupakan 
variabel yang erat kaitannya dengan tugas manajer. Manajer diharapkan mampu memimpin organisasinya dengan baik. Meskipun demikian pemimpin dengan manajer mempunyai pengertian yang berbeda. Seorang manajer yang baik belum tentu merupakan pemimpin yang baik, dan sebaliknya. Idealnya, manajer yang baik juga merupakan pemimpin yang baik (Mamduh, 1997: $362)$.

Menurut Davis, Keith dan Newsroom (1994: 192), kepemimpinan merupakan kemampuan untuk membangkitkan semangat orang lain agar bersedia dan memiliki tanggung-jawab total terhadap usaha mencapai atau melampaui tujuan organisasi. Sedangkan menurut Mochtar (1996: 206), kepemimpinan adalah kemampuan seseorang untuk meyakinkan orang lain agar orang lain itu dengan sukarela mau diajak untuk melaksanakan kehendaknya atau gagasannya. Definisi ini menunjukkan bahwa kemampuan seseorang sangat diutamakan. Kemampuan seseorang secara keseluruhan meliputi keunggulan fisik, mental, dan intelektualnya.

Ada dua fungsi kepemimpinan: (1) Fungsi yang berhubungan dengan tugas atau memecahkan masalah (task-related) yaitu fungsi yang berhubungan dengan tanggung-jawab seorang pemimpin atas pekerjaannya, mencakup pemberian saran penyelesaian kepada bawahan, memberikan pendapat dan informasi kepada bawahan, serta memberikan jalan keluar atau solusi dari permasalahan yang dihadapi bawahannya; (2) Fungsi sosial atau memelihara kelompok (group-maintenance) yaitu fungsi yang berhubungan dengan pemeliharaan kelompok, yaitu segala sesuatu yang dapat membantu kelompok berjalan lebih lancar, persetujuan dengan kelompok lain, penengahan perbedaan pendapat dan perselisihan serta memastikan bahwa individu merasa dihargai oleh kelompok, juga mencakup tindakan mendorong anggota kelompok untuk mencapai tujuan dan menjaga suasana kelompok (Stoner, 1996: 165).

Dalam Islam, kepemimpinan dikenal dengan kata "Imāmah". Menurut Quraish Shihab (2000: 47), imam dan khalifah adalah dua istilah yang digunakan Alquran untuk menunjuk pemimpin. Kata imam diambil dari kata amma-ya'ummu, yang berarti menuju, menumpu, dan meneladani. Kata khalifah berakar dari kata khalafa yang pada mulanya berarti "di belakang". Kata khalifah sering diartikan "pengganti" karena yang menggantikan selalu 
berada di belakang, atau datang sesudah yang digantikannya. Selanjutnya ia menyatakan bahwa Alquran menggunakan kedua istilah ini untuk menggambarkan ciri seorang pemimpin, ketika di depan menjadi panutan, dan ketika di belakang mendorong, sekaligus mengikuti kehendak dan arah yang dituju oleh yang dipimpinnya.

Kemampuan yang harus dimiliki oleh seorang pemimpin dalam Islam, yaitu sebagai berikut: a) Mampu menggerakkan motivasi para bawahan; b) Mampu memberikan tugas kepada bawahan sesuai dengan keahlian masingmasing atau mampu menempatkan orang-orang pada tempat yang sesuai dengan bidangnya. Jika seseorang melakukan sesuatu pada bidangnya, maka seorang pemimpin harus melihat pekerjaan itu bukan semata-mata sebagai sebuah kewajiban, tetapi sebagai sebuah kenikmatan; c) Mampu memberikan reward dan punishment. Reward tersebut tidak mesti berbentuk benda atau materi, akan tetapi bisa saja dalam bentuk pujian atau apa saja yang dapat meningkatkan semangat dan motivasi bawahan. Demikian pula kepada bawahan yang tidak melaksanakan tugas, maka seorang pemimpin harus memberikan punishment atau sanksi, misalnya dalam bentuk teguran; d) Mampu memberikan contoh yang baik. Misalnya jika seorang pemimpin meminta bawahan untuk tepat waktu, maka ia pun harus melaksanakannya. Hal ini diterangkan dalam Alquran Surat Al-Baqarah: 44 sebagai berikut:

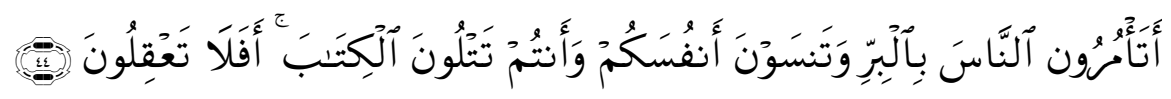

"Mengapa kamu suruh orang lain (mengerjakan) kebajikan, sedang kamu melupakan diri (kewajiban)mu sendiri, padahal kamu membaca Al-Kitab (Taurat)? Maka tidakkah kamu berpikir?" (QS. Al-Baqarah: 144)

\section{Motivasi Kerja}

Adanya suatu organisasi itu dimaksudkan untuk mencapai tujuan yang telah ditetapkan sebelumnya. Pada umumnya tujuan tersebut berupa tujuan jangka panjang, menengah dan jangka pendek. Di sini akan terjadi korelasi positif antara motivasi dan tujuan di mana sekelompok orang dalam suatu kesatuan kerja yang mempunyai sasaran yang jelas, mempunyai moti- 
vasi kerja lebih tinggi dibandingkan kelompok orang yang bekerja tanpa sasaran yang jelas.

Definisi seputar "motivasi" mempersoalkan tentang bagaimana caranya mendorong gairah kerja bawahan, agar mereka mau bekerja keras dengan memberikan semua kemampuan dan keterampilannya untuk mewujudkan tujuan perusahaan (Hasibuan, 1996: 93).

Dengan demikian dapat disimpulkan bahwa motivasi adalah suatu kekuatan yang dapat memberikan rangsangan dan dorongan serta semangat kerja kepada karyawan, dan dapat mengubah perilaku karyawan untuk mau melaksanakan suatu pekerjaan yang ditugaskan kepadanya dengan penuh semangat dan prestasi kerja yang optimal, sehingga tujuan perusahaan akan dapat diwujudkan secara maksimal pula.

Menurut Nuryanto (2009: 30) dalam tesisnya, hukum ketenagakerjaan yang paling mendasar dalam Islam adalah motivasi bekerja hanya untuk Allah SWT. Allah s.w.t. berfirman:

"Allah telah berjanji kepada orang yang beriman dan melakukan pekerjaan yang baik bahwa bagi mereka ampunan Allah dan ganjaran yang besar." (Q.S. Al-An'am : 9).

Ayat ini menunjukkan adanya motivasi kerja yang utuh dalam Islam. Motivasi bekerja untuk mendapatkan ampunan dan ganjaran Allah adalah motivasi terbesar bagi seorang muslim. Untuk itulah bekerja dalam Islam tidak berdiri di ruang hampa yang hanya mengejar "bonus duniawi". Namun lebih dari itu, bekerja dalam ajaran Islam adalah untuk mewujudkan "bonus tidak terhingga" yang telah dijanjikan Allah pada para pelakunya.

Motivasi menjadi sangat penting disebabkan secara naluriah manusia mengharapkan imbalan dari perbuatan yang ia lakukan. Sehingga sekeras apa pekerjaan yang ia lakukan, sebesar itu pula imbalan yang ia terima. Pemahaman terhadap ayat ini tidak hanya berorientasi kepada imbalan akhirat saja. Namun motivasi ini sesuai dengan hukum dunia, yakni seseorang akan mendapatkan sesuatu sesuai dengan besarnya usaha yang ia lakukan. Selain itu, seorang muslim harus selalu mempunyai motivasi bekerja yang tanpa batas. 


\section{Budaya Organisasi}

Menurut Taylor (1887), istilah budaya mula-mula muncul dari ilmu antropologi sosial. Dalam American Heritage Dictionary, definisi budaya diartikan sebagai totalitas pola perilaku, kesenian, kepercayaan, kelembagaan dan semua produk lain dari karya dan pemikiran manusia yang mencirikan suatu masyarakat atau penduduk yang ditransmisikan secara bersama.

Adapun budaya dalam sebuah organisasi, adalah di mana setiap individu memiliki sikap dan perilaku yang berbeda, keperibadian serta sifat yang tetap dan relatif tidak dapat diubah, sehingga ini memberikan suatu acuan untuk mengatur bagaimana individu dalam organisasi berperilaku. Seorang peneliti dan ahli psikologi organisasional Edger H. Schein dalam Suryasudarma (1996: 80) mendefinisikan budaya organisasi sebagai pola dari asumsi-asumsi yang sudah diterima bersama dalam organisasi, dan bisa memecahkan masalah adaptasi ke luar dan integrasi ke dalam organisasi, yang sudah dianggap sah oleh organisasi tersebut dan karena itu harus diajarkan kepada anggota baru sebagai cara bertindak, cara berfikir, cara merasa yang benar dalam berinteraksi dan memecahkan masalah-masalah.

Robbins (1993: 601-602), menjelaskan budaya organisasi merupakan persepsi umum yang dimiliki oleh para anggota organisasi, yaitu merujuk kepada suatu sistem nilai yang dianut bersama oleh para anggota dalam organisasi, sehingga membedakan organisasi tersebut dari organisasi lainnya. Persepsi umum bersama ini merupakan karakter penting yang dijadikan nilai dalam organisasi, sehingga karakter ini dijadikan panutan oleh anggota organisasi.

Dari definisi-definisi budaya organisasi tersebut, dapat disimpulkan bahwa budaya organisasi merupakan nilai, norma, keyakinan dan sikap bersama di dalam organisasi atau kelompok yang disepakati bersama mulai dari inti manajemen sampai kepada karyawan terbawah dalam mewujudkan visi organisasi dan berfungsi sebagai identitas organisasi. Dengan demikian budaya organisasi sangatlah signifikan dengan sikap, cita rasa, keyakinan seorang karyawan akan nilai-nilai dalam organisasi. Jika dilihat dari segi lahiriah adalah sebuah perwujudan sikap batin, seperti perilaku dan hal lain yang dapat diamati secara indrawi. 
Menghadapi era globalisasi saat ini, banyak perusahaan mengadopsi budaya organisasi asing yang diyakini telah maju dan berkembang. Tidak semua budaya asing itu negatif, bahkan budaya asing adakalanya juga bersifat positif, seperti penghargaan atas waktu dan sikap menepati janji. Dalam Islam, organisasi merupakan sebuah kebutuhan, karena merupakan wadah atau tempat berinteraksinya individu dalam melakukan sebuah proses yang dilakukan secara bersama dan untuk tujuan yang sama (Hafidhuddin dan Tanjung, 2005: 27). Implementasi nilai-nilai Islam dalam organisasi, terwujud pada difungsikannya Islam sebagai kaidah berpikir dan kaidah amal, sehingga nilai-nilai ini menjadi nilai utama dalam organisasi.

Suatu budaya organisasi Islami, juga harus mengedepankan kepada nilai-nilai amanah, sikap menepati janji dan kejujuran, kesemuanya tentu harus berintikan nilai yang disepakati secara Islami. Nilai-nilai ini dapat dihayati melalui firman Allah s.w.t. dalam surat al-Mu'minūn: 1-11, di mana keseluruhan ayat ini menjelaskan secara mendetail bahwa amanah, sikap menepati janji dan kejujuran adalah bagian dari budaya Islam. Dengan demikian dalam prakteknya jika masing-masing karyawan dalam pekerjaannya selalu menjaga amanah, benar-benar menepati janji dan bersikap jujur, maka akan memunculkan kekuatan yang luar biasa dalam budaya perusahaan.

Islam membagi budaya kerja kedalam beberapa indikator antara lain: a) Adanya kerja keras dan kerjasama; b) Dalam setiap pekerjaan harus unggul/ profesional/menjadi khalifah; c) Harus mendayagunakan hikmah Ilahi; d) Harus jujur, tidak saling menipu, harus bekerjasama dan saling menguntungkan; e) Kelemah-lembutan; f) Kebersihan; g) Tidak mengkotak-kotakan diri/ukhuwah; h) Menentang permusuhan.

\section{Kinerja Karyawan}

Secara etimologi, kinerja berasal dari kata prestasi kerja (performance). Sebagaimana dikemukakan oleh Mangkunegara (2005: 67) bahwa istilah kinerja berasal dari kata job performance atau actual performance (prestasi kerja atau prestasi sesungguhnya yang dicapai seseorang), yaitu hasil kerja secara kualitas dan kuantitas yang dicapai oleh seorang pegawai dalam melaksanakan tugasnya sesuai dengan tanggung-jawab yang diberikan kepadanya. 
Untuk mecapai kinerja yang baik, diperlukan standar kinerja. Standar kinerja menjelaskan tingkat-tingkat kinerja yang diharapkan, dan merupakan "bahan perbandingan", atau "tujuan", atau "target" tergantung dari pendekatan yang diambil. Standar kinerja harus realistis, terukur dan mudah dipahami atau menguntungkan baik bagi organisasi maupun karyawan.

Terakhir, diperlukan adanya penilaian kinerja. Penilaian kinerja adalah proses evaluasi bagi karyawan dalam mengerjakan tugas mereka seberapa baik ketika dibandingkan dengan satu set standar, dan mengkomunikasikannya dengan bawahan (Tjahjono, 2003: 20). Penilaian kinerja adalah sebuah proses yang meliputi penekanan dan pengkomunikasian kepada pegawai bagaimana pegawai melaksanakan pekerjaan secara ideal.

Penilaian kinerja memiliki dua penggunaan yang umum di dalam organisasi, dan keduanya bisa merupakan konflik yang potensial. Salah satu kegunaannya adalah mengukur kinerja dalam rangka memberikan penghargaan atau dengan kata lain untuk membuat keputusan administratif mengenai karyawan. Kegunaan lainnya adalah untuk pengembangan potensi individu. Pada kegunaan ini, para manajer ditampilkan lebih sebagai seorang konselor dari pada seorang hakim, dan atmosfernya sering kali berbeda. Penekanannya adalah identifikasi potensi dan perencanaan terhadap arah dan kesempatan pertumbuhan karyawan.

Jadi kita bisa ambil kesimpulan bahwa penilaian kinerja adalah proses untuk mengetahui dan pengamatan atas kinerja, apakah kinerja itu baik atau tidak. Penilaian kinerja ini dapat dijadikan sebagai pedoman mengetahui apakah seorang karyawan bekerja dengan baik atau tidak. Oleh karena itu melalui penilaian akan diperoleh hasil yang akurat tentang kemampuan pekerja yang sesungguhnya.

Gaya kepemimpian, motivasi kerja dan budaya organisasi merupakan variabel yang berkesinambungan. Dalam penelitian ini tiga variabel tersebut digunakan untuk menganalisis kinerja karyawan di sebuah perusahaan, yaitu perusahaan Bank Muamalat Indonesia cabang Surakarta. Adapun skema kerangka berpikirnya dapat dilihat sebagai berikut: 


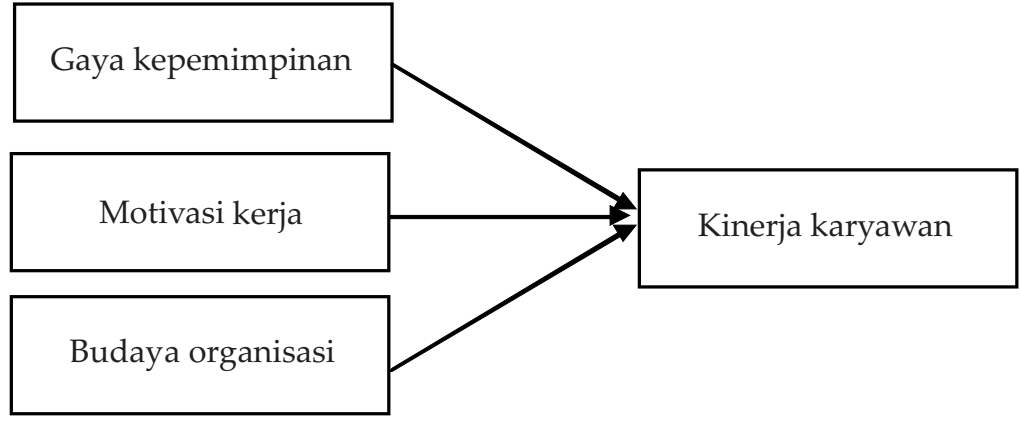

Sesuai dengan kerangka berpikir di atas, maka peneliti mengambil hipotesis atau dugaan sementara, yaitu:

1. H1 : Gaya kepemimpinan berpengaruh positif terhadap kinerja karyawan.

2. H2 : Motivasi kerja berpengaruh positif terhadap kinerja karyawan.

3. H3 : Budaya organisasi berpengaruh positif terhadap kinerja karyawan.

\section{Metodologi Penelitian}

Metode penelitian ini adalah survei dengan pendekatan penelitian lapangan (field research), untuk menguji korelasi antara variabel dengan kondisi lingkungan penelitian yang natural dan tingkat keterlibatan penelitian yang minimal (Indriantoro dan Supomo, 1999: 92). Penelitian ini juga bertujuan untuk mengumpulkan data sebanyak-banyaknya, sehingga setelah dianalisa diharapkan hasilnya bisa dijadikan hipotesa untuk penelitian berikutnya (Mardalis, 1995: 25). Adapun objek penelitian adalah Bank Muamalat Indonesia Cabang Surakarta dengan materi kajian untuk menguji hubungan antara gaya kepemimpinan, motivasi dan budaya organisasi terhadap kinerja karyawan di Bank Muamalat Indonesia Cabang Surakarta.

Pendekatan yang digunakan pada penelitian ini adalah pendekatan penelitian expost facto, yaitu survei yang dilakukan untuk tujuan eksplanasi (untuk menjelaskan hubungan antar variabel) dan juga menggunakan semangat penelitian eksperimental dengan berdasar pada data yang sudah ada (Faisal, 2001: 102), yaitu data primer yang diperoleh dari kuesioner atau hasil jawaban angket yang diajukan kepada seluruh karyawan di Bank Muamalat Indonesia Cabang Surakarta dan didukung oleh data-data sekunder lainnya. 


\section{Pembahasan}

Hasil analisis dalam penelitian ini menunjukkan bahwa gaya kepemimpinan berpengaruh positif dan signifikan terhadap kinerja karyawan. Hal ini ditunjukkan oleh nilai signifikan kurang dari 0,05 yaitu sebesar 0,01 . Hal ini berarti gaya kepemimpinan akan mempengaruhi banyak orang untuk mencapai tujuan, dengan cara memberi petunjuk atau perintah, yang dapat mempengaruhi orang lain, sehingga menyebabkannya mau bertindak dan menimbulkan perubahan positif. Untuk mencapai keberhasilan dalam memimpin sebuah organisasi, maka seorang pemimpin harus dapat dipercaya bawahannya dalam ucapan maupun tindakan. Selain itu ia juga harus memiliki pengaruh yang kuat terhadap bawahannya, mengetahui karakter bawahannya, dan mampu menyesuaikan diri dengan lingkungannya.

Dalam hadis Nabi s.a.w. disebutkan bahwa setiap kita adalah pemimpin. Dalam kehidupan sehari-hari, manusia sebenarnya telah melakukan unsur-unsur gaya kepemimpinan, seperti mempengaruhi, mengajak, memotivasi, dan mengkoordinasi sesama mereka.

Adapun pengaruh motivasi kerja terhadap kinerja karyawan, hasil analisis dalam penelitian ini menunjukkan bahwa motivasi kerja berpengaruh positif dan signifikan terhadap kinerja karyawan. Hal ini ditunjukkan secara signifikan dengan nilai kurang dari 0,05, tepatnya yaitu sebesar 0,02 . Hal ini berarti semakin tinggi tingkat motivasi kerja akan semakin meningkatkan kinerja karyawan. Untuk meningkatkan kinerja karyawan, pemimpin memberikan motivasi kepada karyawan Bank Muamalat Cabang Surakarta melalui kebutuhan, semangat kerja, maupun kinerja karyawan. Motivasi kerja dalam Islam adalah motivasi bekerja hanya untuk Allah. Allah s.w.t. telah berfirman:

"Allah telah berjanji kepada orang yang beriman dan melakukan pekerjaan yang baik bahwa bagi mereka ampunan Allah dan ganjaran yang besar" (QS. Al An'am: 9).

Sedangkan pengaruh budaya organisasi terhadap kinerja karyawan, hasil analisis dalam penelitian ini menunjukkan bahwa budaya organisasi berpengaruh positif dan signifikan terhadap kinerja karyawan, hal ini ditunjukkan oleh nilai signifikan kurang dari 0,05 yaitu sebesar 0,02 . Hal ini 
berarti budaya organisasi yang sejalan dengan fungsinya akan memberikan pengaruh positif kepada karyawannya. Budaya organisasi merupakan normanorma dan nilai-nilai yang mengarah pada perilaku anggota organisasi dan pembentukan kepribadian yang mapan.

"Dialah yang menjadikan bumi itu mudah bagi kamu, maka berjalanlah di segala penjurunya dan makanlah sebahagian dari rezekiNya. Dan hanya kepada-Nyalah kamu (kembali setelah) dibangkitkan" (QS.Al-Mulk: 15).

Dengan budaya organisasi, manusia bisa memiliki banyak kesempatan untuk membentuk kepribadian yang mapan, sehingga rezeki Allah akan datang, sesuai dengan usahanya berdasarkan norma-norma dan nilai-nilai yang telah ditetapkan.

\section{Kesimpulan}

Berdasarkan hasil analisis data dan pembahasan, maka dapat diambil kesimpulan bahwa terdapat pengaruh positif yang signifikan antara gaya kepemimpinan, motivasi kerja dan budaya organisasi terhadap kinerja karyawan pada Bank Muamalat Indonesia Cabang Surakarta yaitu sebesar $(0,01),(0,02)$ dan $(0,01)$, karena penelitian dikatakan signifikan ketika nilainya kurang dari 0,05 .

Sedangkan variabel yang berpengaruh dominan terhadap kinerja karyawan pada Bank Muamalat Indonesia Cabang Surakarta adalah gaya kepemimpinan. Hal ini dapat ditunjukkan dengan nilai standarized beta variabel gaya kepemimpinan sebesar 0,451 . Nilai ini lebih tinggi dibandingkan dengan nilai standarized beta variabel motivasi kerja dan budaya organisasi.

\section{Daftar Pustaka}

Brahmasari, Ida Ayu dan Agus Suprayetno. 2008. "Pengaruh Motivasi Kerja dan Budaya Organisasi terhadap Kepuasan Kerja Karyawan serta Dampaknya pada Kinerja Perusahaan Studi Kasus pada PT. Pei 
Hai International Wiratama Indonesia" dalam Jurnal Manajemen dan Kewirausahaan, Vol. 10, No. 2, September.

Davis, Keith dan Newstrom, John W. 1995. Perilaku dalam Organisasi edisi ketujuh. Jakarta: Erlangga.

Effendy, Ek Mochtar. 1996. Manajemen Suatu Pendekatan Berdasarkan Ajaran Islam. Jakarta: Bhatara.

Faisal, Sanapiah. 2001. Format-Format Penelitian Sosial. Edisi Pertama. Cetakan Kelima. Jakarta: PT. Raja GrafindoPersada.

Hasibuan Malayu S.P. 1996. Dasar-Dasar Perbankan. Jakarta: Bumi Aksara. Kreitner, Robert, dan Angelo Kinicki. 2003. Perilaku Organisasi. Edisi Pertama. Jakarta: PT. Salemba Emban Patria

Mangkunegara, Anwar Prabu. 2005. Manajemen Sumber Daya Manusia Perusahaan. Cetakan Keenam PT. Remaja Rosdakarya Bandung.

Mardalis. 1995. Metode Penelitian Suatu Pendekatan Proposal. Cetakan III. Jakarta: Bumi Aksara.

Mamduh, M. Hanafi. 1997. Manajemen. Yogyakarta: UPP AMP YKPN.

Nawawi, Hadari H. 2001. Manajemen Sumber Daya Manusia untuk Bisnis yang Kompetitif. Yogyakarta: Gajah Mada University Press.

John, R Shchermerhorn Jr. 2000. Manajemen ed. 1. Yogyakarta: ANDI.

Robbins, Stephen P. 1993. Organizational Behavior. New Jersey: PrenticeHall.

Suryasudarma, B.M.S., S.J. 1996. Budaya Organisasi sebagai Faktor Kunci Keberhasilan di dalam Dunia Industrial, dalam Romo Kadarman Kenangan dan Persembahan bagi A.M. Kadarman S.J, Yogyakarta: Universitas Sanata Dharma.

Stoner, Jamer A. F. 1996. Manajemen. Alih bahasa: Alexander Sindoro. Jakarta: PT Prenhallindo.

Taylor, Edward B. 1887. Primitive Culture: Research Into The Development of Mythology, Philosophy, Religion, Art and Custom. Jilid II. New York: Henry Holt.

Wursanto. 2003. Dasar-Dasar Ilmu Organisasi. Yogyakarta: Andi Offset. 